


\section{Increasing Management Relevance and Competitiveness}

\section{Editors}

Badri Munir Sukoco, Rahmat Heru Setianto \& Nidya Ayu Arina Universitas Airlangga, Indonesia

Ade Gafar Abdullah, Asep Bayu Nandiyanto \& Ratih Hurriyati Universitas Pendidikan, Indonesia

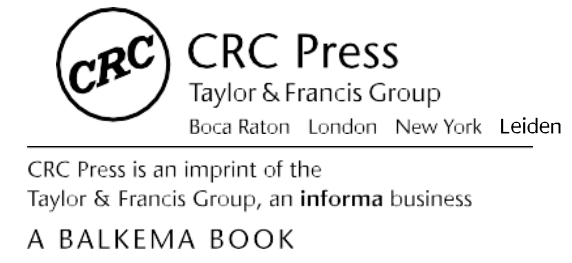


CRC Press/Balkema is an imprint of the Taylor \& Francis Group, an informa business

(c) 2018 Taylor \& Francis Group, London, UK

Typeset by V Publishing Solutions Pvt Ltd., Chennai, India Printed and bound in Great Britain by CPI Group (UK) Ltd, Croydon, CR0 4YY

All rights reserved. No part of this publication or the information contained herein may be repro-duced, stored in a retrieval system, or transmitted in any form or by any means, electronic, mechanical, by photocopying, recording or otherwise, without written prior permission from the publisher.

Although all care is taken to ensure integrity and the quality of this publication and the information herein, no responsibility is assumed by the publishers nor the author for any damage to the property or persons as a result of operation or use of this publication and/or the information contained herein.

Published by: CRC Press/Balkema

Schipholweg 107C, 2316 XC Leiden, The Netherlandse-mail:

Pub.NL@taylorandfrancis.com www.crcpress.com -

www.taylorandfrancis.com

ISBN: 978-0-8153-7455-8 (Hbk)

ISBN: 978-1-351-24189-2 (eBook) 


\section{Table of contents}

Preface $\quad x i$

Acknowledgements $\quad$ xiii

$\begin{array}{ll}\text { Organizing committees } & \text { XV }\end{array}$

\section{Strategic management, entrepreneurship and contemporary issues}

Governance of financial intangible success factors: An option in building business resilience and sustainability

P. Sugito

The influences of the alliance learning process and entrepreneurial orientation on the strategic alliance performance of Indonesian construction companies

$R$. Handayani \& R. Dyah Kusumastuti

Assessing necessity and opportunity-based entrepreneurship: An analysis of demographic characteristics, propensity for new ventures and entrepreneurial motivation (a study of labor forces and entrepreneurs in Padang, Indonesia)

H. Rahman \& D. Lesmana

Critical assessment on zakat management: Zakat scorecard model

T. Widiastuti, S. Herianingrum \& I. Mawardi

Investigating entrepreneurial orientation impact on project performance in highly regulated industry: A case of renewable power industry in Indonesia

F.A. Firman, R.D. Kusumastuti, H.T. Kurniawan \& I.M. Ruky

How to survive in the modern era: Integrated local entrepreneurs, the traditional market and the modern store

P.P.D. Astuti, Y. Setyowati \& A.A.G.S. Utama

The influence of Islamic service quality toward bank customer loyalty and satisfaction of BRISyariah Surabaya

M.Q. Fauzi, S. Herianingrum, T. Widiastuti \& R.P. Putra

Management accounting practices in micro enterprises in the Sleman Regency, Daerah Istimewa Yogyakarta

A.C. Laksmi \& A.P. Putra

The power of finance: The dynamics of female entrepreneurs in fulfilling their financial needs M.R. Rita, S. Wahyudi \& H. Muharam

Entrepreneurial orientation in a family business group: The role of the corporate center and its effect on business unit performance O. Pendrian, K.A. Karnen, R. Rachmawati \& R.D. Kusumastuti

Developing entrepreneurship for the performing arts community through an art incubation model 
analytical hierarchy process

The influence of entrepreneurship orientation and management capability on performance of small and medium enterprises in Bogor

A. Setyo Pranowo, H. Hari Mulyadi, Z. Musannip Efendi Siregar \&

Y. Hendayana

The influence of family factors on expatriate performance

N. Kartika

Is firm size an important determinant for firms in establishing political connections?

N.N. Amorita, D. Agustia \& I. Harymawan

Integration of corporate social responsibility and resource based theory to create

and capture value

N. Nandang \& H. Mulyadi

Organizational behavior, leadership and human resources management

Superior performance model of human resources

T. Yuniarsih, Disman \& M.D. Sugiharto

The impact of fiscal decentralization on economic growth and manpower absorbed at districts/cities in South Kalimantan Province Muzdalifah \& R. Purwono

Work-family conflict and satisfactions: A job demand-resources model perspective

J. Sulistiawan

Building employee engagement through transformational leadership, psychological empowerment and affective commitment

P. Yulianti \& N. Hamidah

The impact of transformational leadership, learning organization and job autonomy on creative self-efficacy

I.B.G.A. Permana \& W. Astiti

Enhancing commitment to organizational change initiative and performance outcomes

N.A. Arina \& P. Yulianti

The influence of Perception of Usefulness (PoU) and Perceived Ease of Use (PEU)

on the perception of information system performance

F. Sayekti \& L.E. Wijayanti

Knowledge sharing benefits: The contingency effects of environmental contexts

A. Qomariyah

The antecedents of entrepreneurial intentions in students of Airlangga university

(A study of student participants in WEBS in the faculty of economics and business)

P. Yulianti \& I.G.N.W.H. Saputra

Effect of proactive personality and Organizational Support for Career Development (OSCD) on career satisfaction and job performance

V. Octia \& D. Ratmawati

The effects of transformational and transactional leadership on work performance of middlelevel leaders with organizational commitment as mediator: A study of state-owned company, Pelabuhan Indonesia III Inc.

A. Eliyana, S. Maarif \& R.J. Sunarsono

Transformational leadership style, team performance and team job satisfaction:

Mediation by levels of cognitive trust and collective efficacy

P. Yulianti \& R. Sanjaya

The impact of self-efficacy and perceived organizational support on operational managers' readiness to change

H. Prima \& A. Eliyana 


\section{Marketing management}

Factors affecting customer retention in a priority banking program

I.R. Aliyah, S. Soebandhi \& A. Baktiono

The impact of messages assertiveness on compliance with perceived importance as a moderation variable on the anti-cigarette campaign in Surabaya

Kristiningsih, R.S. Wuryaningrum \& A. Trimarjono

Demographic variables and environmentally friendly behavior in a developing country T. Handriana

Antecedents and consequences of ongoing search information

D.T. Firmansyah \& D. Mardhiyah

Role of negative brand name perception and religiosity on brand attitude

S. Gunawan \& R.T. Ratnasari

The effects of good/bad news on consumer responses toward higher education

G.C. Premananto \& M.H. Hanafiah

Examining leadership style and advertising evaluation on employees'

customer focus

R.A. Aisyah \& N.A. Arina

The effect of airline sale promotion types on consumers' attitudes toward brand and purchase intentions

M. Kurniawati

The influence of celebgrams, e-WOM, and pictures on impulse buying

Hartini, Sri \& Uswatun

Value propositions of supermarkets

R. Rinawati

Empirical study of perceived quality information and perceived information security impact on online purchasing in Indonesia

L. Lisnawati, L.A. Wibowo \& P. Andi

Measuring religiosity and its effects on attitude and intention to wear a hijab:

Revalidating the scale

H.A. Wibowo \& M.R. Masitoh

\section{Management and economics education}

Communication skills of accountants and managers in Indonesia

Y.L. Rudianto \& A.R. Sridadi

Factors knowledge management and the work motivation of lecturers

Rino

The role of talent management in student performance in higher education

D. Purwaningsih

Strategy to build universities

P. Dewi Dirgantari, B. Widjajanta \& L. Lisnawati

Factors affecting the improvement of students' Grade Point Average (GPA)

A.B. Santoso, E.C.M. Simatupang \& R.H. Sofyandi

Innovation, operations and supply chain management

Analysis of the small segment credit business process at Bank ABC Indonesia

A.C. Saifullah \& R.D. Kusumastuti

The identification of defects in rubber slipper production using the six sigma method

T.A. Auliandri \& M.A. Setiani

The design of service quality improvement in a library by using LibQUAL model and fishbone diagram 
The strategic role of Indonesia in Global Value Chains (GVC)

M.A. Esquivias, D.W. Sari \& R.D. Handoyo

Service innovation: The moderating effects of environmental contingencies

N. Anridho

Efficiency and total-factor productivity in the manufacturing industry in

33 provinces of Indonesia

Muryani

Academic excellence and total quality supply chain management in higher education

I. Usman \& Windijarto

\section{Financial management and accounting}

The influence of usage accounting information on small medium enterprise's perception

S. Mintarti, D.M. Sari \& T. Fitriastuti

Determinants of banks' net interest margin in five South East Asian countries

M. Gitanadya \& R. Setiawan

The effect of monetary policy and macroeconomic variables on foreign portfolio investment in Indonesia

N.F. Anne \& R. Purwono

Internal factors, external factors, and bank liquidity in Indonesia

I.M. Sudana \& A.F. Akbar

The obstacles in developing Indonesia's sovereign sukuk

N. Laila, F.F. Hasib \& M. Anshori

The effect of trading volume changes on JKSE's market return

M. Madyan, S. Hasan \& D.F. Putri

The influence of the profitability indicator, capital and performing loans on the

liquidity of the bank in the Indonesian stock exchange

O.V.B. Nainggolan

Corporate governance performance evaluation of banks operating in Indonesia

F. Budhijono

What drives finance pattern debt companies to pay dividends in Indonesia?

L. Gestanti \& G. Memarista

Diversification, firm value and government ownership

S.A. Usman \& C. Sulistyowati

Do operating costs, investment returns and claims have an effect on contributions?

D.F. Septiarini

Crowdfunding new paradigm for financing: Operational pattern of crowdfunding in Indonesia

S.R. Arifin \& Wisudanto

Different ways to solve the liquidity problem of Indonesian Islamic microfinance

I. Mawardi \& T. Widiastuti

Determinant of banks stock risk in Indonesia

R. Setiawan \& R. Anggraeni

Degree of internationalization and firm financial performance

F. Ismiyanti

Cost efficiency of Indonesian banks over different groups of capital

M. Anwar

Analysis of investor preference in investing on initial public offering

M. Sari

Female directors, nationality diversity, and firm performance: Evidence from the mining industry in Indonesia

Y.S. Putri, M. Nasih \& I. Harymawan

Sharia governance framework in Islamic banking and financial institutions in Indonesia: 


\title{
Crowdfunding new paradigm for financing: Operational pattern of crowdfunding in Indonesia
}

\author{
S.R. Arifin \& Wisudanto \\ Universitas Airlangga, Surabaya, Indonesia
}

\begin{abstract}
This article aims to confirm crowdfunding as being a new phenomenon in funding, especially for a millennial business entrepreneur. The development of crowdfunding in Indonesia is facing challenges and opportunities because crowdfunding is a new type of intermediary funding which uses innovation in technology. This article explores Indonesian crowdfunding development, and the awareness of millennial business entrepreneurs to access this funding. Descriptive analysis method found that there are two operational patterns of crowdfunding platforms in Indonesia, and the lending-based is four times bigger than donation-based. In recent years, they collected 455 billion rupiahs and involved 304,467 entities users. The research is also resulting in potential development towards crowdfunding.
\end{abstract}

\section{INTRODUCTION}

In recent years, the world has been introduced to an alternative way to gain access to finance, knownas crowdfunding. It raises funds from a large soci-ety or 'crowd', using Internet-based platforms involving a large number of people. In 2014, global crowdfunding collected $\$ 16.2$ billion, almost three times more than in 2013 (Massolution, 2015). In Indonesia, the six leading crowdfunding platforms raised over 505.3 billion rupiahs.

The total funds raised by banking in Indonesia reached 4.334 trillion rupiahs, while the capital market raised a total fund of some 34.3 trillion rupiahs. Venture capital collected 8.15 trillion rupiahs, while crowdfunding only collected 0.5 trillion rupiahs. Despite some funds collected by crowdfunding being relatively small compared to existing funding models such as banking, capital markets, and venture capital, its potential is very likely to become larger in the future.

The crowdfunding model is readily available to anyone. Therefore, it will be able to reduce the market share of traditional financial institutions, such as banking and capital markets, in direct or indirect ways. The crowdfunding model can easily go viral on the Internet, so the funds collected from the Internet can reach a sizable amount. Compared to bank-ing and capital markets, the crowdfunding model is more unregulated, and consequently the investment environment is more vulnerable and insecure.

On the one hand, crowdfunding can reach many people previously unreachable by traditional financial services. The ease of use that crowdfunding offers, allows it to reach non-bankable small to medium enterprises SMEs, and people with low literacyor uneducated in financial investment. It strongly supports the financial inclusion and financial literacy programs proclaimed by regulators, such as Indonesian Central Bank (BI) and Indonesian Financial Service Authority (OJK). Therefore, the funds collected by financial institutions are fully utilized by the business world.

The main focus in this article is on the operational pattern of crowdfunding in Indonesia. This article aims to form a big map of the operational pattern of crowdfunding in Indonesia, consisting of the types, sizes, regulations, and parties involved in the whole crowdfunding process and development. By knowing the map, it is expected to answer what issues are inherent in the new model of financial intermediation, such as the potential and the challenges faced.

\section{LITERATURE REVIEW}

\subsection{Crowdfunding}

Valančienè and (2014) define crowdfunding as being a method to connect entrepreneurs who want to increase capital, with new investors who have excess capital resources and want to invest small amounts through Internet-based intermediary entities.

Crowdfunding can be divided into four categories, according to the funding base offered by the crowdfunding platform. The four categories are donation, pre-selling, lending and equity crowdfunding (Vulkan et al., 2016).

Three main stakeholders in the crowdfunding process are entrepreneurs, crowdfunding platforms and investors (backers). Each stakeholder has its roles and interests. The first line starts from 


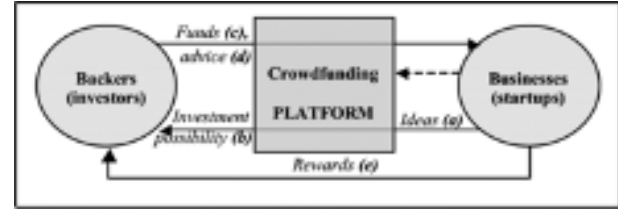

Figure 1. Crowdfunding process framework. Source: Valančienè and Jegelevičiūtė (2014).

entrepreneurs (business or startups) proposing ideas, funding requests through the crowdfunding platform and promising returns to investors. Backers (investors) will see the investment opportunities offered by entrepreneurs, who can then give funding commitment or advice. The crowdfunding platform serves as an intermediary that connects investors and backers (Valančienè \& Jegelevičiūtè, 2014).

\subsection{Financial intermediary institution and financial innovation}

The main function of the financial system is to collect funds from the surplus unit and distribute it to the deficit unit. One of the main parts of the financial system is the intermediary financial institutions, such as banks and capital markets (Boot \& Thakor, 1997).

The development of the financial system demands a change known as the spiral of innovation (Merton \& Bodie, 1995). Technological advancement makes it possible to achieve high efficiency, and it can be used to reduce transaction costs. Low transaction costs, in theory and practice, will encourage broad changes in the future of financial institutions (Merton \& Bodie, 1995).

The new emerging type of funding entity in the millennial age is called crowdfunding. These entities have different characteristics from traditional financial institutions, such as banks and capital markets. Crowdfunding is not only an intermediary financial entity but also loci of social interaction that forms private social capital among supporters of crowdfunding. These characteris- tics distinguish between crowdfunding and other funding sources (Colombo et al., 2015). Internal social capital can also be obtained outside the crowdfunding supporters communities, such as from family and friends (Agrawal et al., 2011) and through social media (Mollick, 2014).

\section{METHOD}

\subsection{Descriptive method}

This article uses the descriptive research method to discover the operational pattern of crowdfunding in Indonesia. Descriptive research is a study aimed at describing events or situations. This type of research is not intended to prove correlation, testing hypotheses, forecasting and getting implications and meaning (Suryabrata, 2000).

Descriptive research to answer the research problem consists of three stages. Stage I is searching the crowdfunding platform websites using search engines, by entering certain search keywords to get a list of active crowdfunding platforms in Indonesia. Keywords used are 'crowdfunding in Indonesia' and 'P2P lending in Indonesia'. Stage II is conducting a content analysis on each platform site on the list that has been made. Stage III is to increase the objectivity of the result by surveying every crowdfunding platform site on the list. We simply confirm information about the operating base, the amount of funds collected and the total users on their platform.

\subsection{Research object and subject}

The research object in this article is the operational pattern of a crowdfunding platform and its development potential. Topics in this study are the content displayed by crowdfunding platforms and the crowdfunding platform managers.

\subsection{Operationalization of variables}

Operationalization of variables aims to know the measurement of variables at the level of practice and reality. The operational definitions of each variable in this study are as follows.

\subsubsection{Amount of crowdfunding}

Crowdfunding is an Internet-based intermediary entity (Valančienė \& Jegelevičiūtè, 2014). The variable measured as one website address counts as one platform.

\subsubsection{Size}

Company size is the number of users involved in the financial institution. Users of crowfunding platform consist of investors and startups. Each entity who participate in crowdfunding platform whether as an investors or startups, counted as one user. The total amount of funds raised from funding activity is a proxy for company size.

\subsubsection{Type}

Crowdfunding type can be categorized as donation-based, pre-selling, lending and equity crowdfunding (Vulkan et al., 2016). It is identified from the funding and financing mechanisms offered by crowdfunding platforms. When, in the platform, it describes or mentions 'donate', it is identified as being donation-based crowdfunding. So that 'lend' is lending-based, or 'invest' and 'return' are equity-based crowdfunding. 


\section{RESULT}

\subsection{Number of crowdfunding platforms in Indonesia}

The finding through search engines to collect a list of crowdfunding platforms in Indonesia indicates active and inactive crowdfunding platforms. Table 1 is a list of current crowdfunding in Indonesia.

The crowdfunding platforms that became inactive during this research-in 2017 - was 'Wujudkan', with the website address www.wujudkan. com, and 'Ayo Peduli' at www.ayopeduli.com. The closure of the 'Wujudkan' platform was due to an inability to collect complete funded projects of more than $12 \%$. This made the manager feel unable to fulfill their responsibilities as a good funder. Therefore, the manager decided to close the site.

\subsection{Crowdfunding size}

The identified crowdfunding platforms were then analyzed regarding the content to determine the size of crowdfunding. The content of crowdfunding is used to measure its size, and also shows the number of participants involved, both as investors (backers) as well as accessing funds.

The total funds collected by each crowdfunding platform can also be a measure of the size of the crowdfunding platform, in addition to the number of people involved as users.

\subsection{Types of crowdfunding in Indonesia}

The identified crowdfunding platform was then analyzed as regards to its content, to determine the operational base of each platform. According to Vulkan et al. (2016), there are four crowdfunding types: donation, pre-selling, lending and equity crowdfunding. Referring to Vulkan's categories, then the type of crowdfunding in Indonesia today consists of only two kinds of categories-donations and lending. Pre-selling and equity-based schemes no longer exist.

The donation-based crowdfunding platform operates on a fundraising basis from the community

Table 1. Crowdfunding platforms in Indonesia.

\begin{tabular}{ll}
\hline Website address & Platform name \\
\hline www.kitabisa.com & Kitabisa \\
www.gandengtangan.org & GandengTangan \\
www.modalku.co.id & Modalku \\
www.investree.id & Investree \\
www.koinworks.com & Koinworks \\
www.amartha.com & Amartha \\
www.crowdo.co.id & Crowdo \\
\hline
\end{tabular}

Source: Author's compilation.
Table 2. Crowdfunding platform size in Indonesia.

\begin{tabular}{lll}
\hline Total users & Total fund raised* & Platform name \\
\hline 103.8 & 289.981 & Kitabisa \\
0.3 & 1.05 & GandengTangan \\
151.2 & 1.072 & Modalku \\
122 & 2.219 & Investree \\
Unknown & 8.059 & Koinworks \\
78 & 3.2 & Amartha \\
50 & 34 & Crowdo \\
\hline
\end{tabular}

*In billion rupiah.

Source: Author's compilation.

Table 3. Crowdfunding types in Indonesia.

\begin{tabular}{ll}
\hline Type & Platform name \\
\hline Donation-based & Kitabisa \\
Lending-based & GandengTangan \\
Lending-based & Modalku \\
Lending-based & Investree \\
Lending-based & Koinworks \\
Lending-based & Amartha \\
Lending-based & Crowdo \\
\hline
\end{tabular}

Source: Author's compilation.

in the form of voluntary donations, to distribute charitable projects or activities with the objective of bettering humanity. The lending-based crowdfunding platform operates as an intermediary party, just like a bank. The platform collects funds from the community as funds disbursed to the borrowers. The borrower is obligated to repay the principal and interest according to the contract. The crowdfunding platform will return the funds invested by the lender, along with the promised interest.

\subsection{Potential development of crowdfunding in Indonesia}

\subsubsection{Growth of SMEs}

The result of content analysis on crowdfunding platforms in Indonesia shows that the main target of crowdfunding financing is SMEs. SMEs are the strategic market of the crowdfunding business model. If we look at the data of Indonesia's SMEs in 2013 , it recorded as many as $57,895,721$ units with an average annual growth of $2.41 \%$ per year since 2009. It has become a major opportunity for crowdfunding platforms to expand the market.

\subsubsection{Millennial generation in Indonesia}

The millennial generation is a generation born between 1980-2000. The millennial characteristics are closely related to the digital world. Millennials grow and evolve together with broadband, 
smartphones, laptops, and social media, which have become the norm, and millennials demand fastaccess to information and flexibility (PWC, 2011).

Based on the 2010 census, the millennial generation in Indonesia reached $36 \%$ of the total Indonesian population of 238 million. Currently, the main decision-makers are generation X. In 2020, the millennial generation is projected to be $31 \%$ of the total population of Indonesia. Someday, when a demographic transition occurs whereby millen- nials are the main decision-makers, crowdfunding as a digital platform will have major opportunities for the growth and will be increasingly needed as ameans of investment.

\subsubsection{Regulation}

Lending-based crowdfunding platforms have been regulated by the Financial Services Author- ity of the Republic of Indonesia through the Financial Services Authority Regulation No. 77/ POJK.01/2016 on Information Technology-Based Lending Services. The lending-based crowdfund- ing platform (known as P2P lending), is included in the regulation in the category of 'Other Financial Institutions', such as pawnshops, export financing institutions and secondary housing finance com- panies (OJK, 2016).

This rule ensures security for crowdfunding users. This regulation requires that crowdfunding platforms should be in the form of a limited liabil-ity company or a cooperative. The existence of this regulation further reinforces that there is support and supervision from the government concerning Internet-based financial services. The weakness of this rule is that it has not yet covered the dona- tionbased crowdfunding platform. Moreover, the regulation does not consider that one day there may also be a crowdfunding platform that offersequitybased schemes.

\section{CONCLUSION AND DISCUSSION}

The results of this study show a big map of the operational pattern of crowdfunding in Indonesia. The crowdfunding type in Indonesia currently only consists of two kinds: crowdfunding based on donations, and lending-based. The total size of crowdfunding counted from total users is 304,467 entities. The size in total funds collected reached 455 billion rupiahs. This measure, compared to traditional financial intermediary institutions such as banking and the capital market, is relatively small and quite insignificant in amount.

The development of crowdfunding will continueto grow as the number of SMEs grows as the main market of the majority of crowdfunding plat- forms. Crowdfunding opportunities will also grow with the demographic shift in which $\mathrm{X}$ generation will changed by the millennial generation, who will subsequently become the major decision-makers in many sectors of life and business.

Regulation is necessary as a legal means to ensure the safety of the users of crowdfunding. With this support, the crowdfunding platform can still be well developed without ignoring the secu- rity and convenience aspects for the users. Those aspects can increase trust from users.

In the millennial age, crowdfunding has become the main topic of financial issue. Research on the risk of crowdfunding becomes necessary in the first place to complement existing regulations, so that the level of security when using crowdfundingis better, without hampering the development of innovation from the finance.

\section{REFERENCES}

Agrawal, A.K., Catalini, C. \& Goldfarb, A. (2011). Geography of crowdfunding (No.W16820). National Bureau of Economic Research.

Boot, A.W. \& Thakor, A.V. (1997). Financial system architecture. The Review of Financial Studies, 10(3), 693-733. Colombo, M.G., Franzoni, C. \& RossiLamastra, C.

(2015). Internal social capital and the attraction of early contributions in crowdfunding. Entrepreneurship Theory and Practice, 39(1), 75-100.

Massolution, C.L. (2015). Crowdfunding industry report. Retrieved from http://reports.crowdsourcing. org/index.php?route $1 / 4$ product/product\&product id1/454\#oid1/41001_23_banner_38.

Merton, R.C. \& Bodie, Z. (1995). A conceptual framework for analyzing the financial system. The Global Financial System: A Functional Perspective, 3-31.

Mollick, E. (2014). The dynamics of crowdfunding. An exploratory study. Journal of Business Venturing, 29(1), 1-16.

OJK. (2016). Salinan Peraturan Otoritas Jasa Keuan- gan No. 77/POJK.01/2016 tentang Layanan Pinjam Meminjam Uang Berbasis Teknologi Informasi [Copyof Indonesian Financial Services Authority No.77/ POJK.01/2016 about Financial Service based on Information Technology]. Retrieved from http:// www.ojk.go.id/id/regulasi/otoritas-jasa-keuangan/ peraturan-ojk/Documents/Pages/POJK-Nomor-77POJK.01-2016/SAL\%20\%20POJK\%20Fintech.pdf. Accessed at March 2nd 2017.

PWC. (2011). Millennial at work reshaping the workplace. Retrieved from http://www.pwc.com/en_M1/m1/services/consulting/documents/millennials-at-work.pdf. Accessed March 7th 2017.

Suryabrata, S. (2000). Metode penelitian [Research Method]. PT. Raja Grafindo Persada, Jakarta.

Valančienè, L. \& Jegelevičiūtè, S. (2014). Crowdfunding for creating value: A stakeholder approach. ProcediaSocial and Behavioral Sciences, 156, 599-604.

Vulkan, N., Åstebro, T. \& Sierra, T.M.F. (2016). Equity crowdfunding: A new phenomena. Journal of Business

Venturing Insights, 5, 37-49. 